\section{Caballito de mar}

\section{Seahorse}

\author{
D. Soliva Martínez I. Belda González
} 1 Servicio de Diagnóstico por imágenes, Hospital Virgen de la Luz,
Cuenca, España

Rev Argent Radiol 2020;84:110.

Se muestra una imagen de tomografía computada poscontraste oral e intravenoso en el plano coronal que muestra un íleon terminal normal, distendido y relleno de

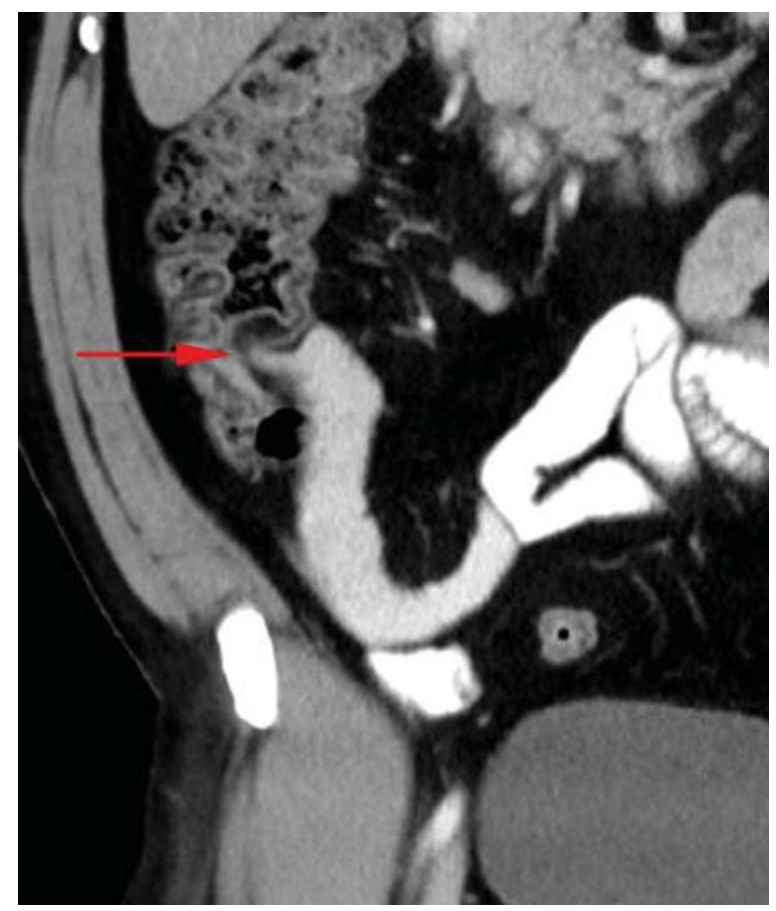

Fig. 1 Tomografía computada poscontraste oral e intravenoso en el plano coronal.
Address for correspondence D. Soliva Martínez (e-mail: radcuenca@gmail.com).

contraste oral, conformando discretamente una letra S itálica, cuya luz se afina a nivel de la válvula ileocecal (-Fig. 1). Esta imagen recuerda a un caballito de mar (-Fig. 2).

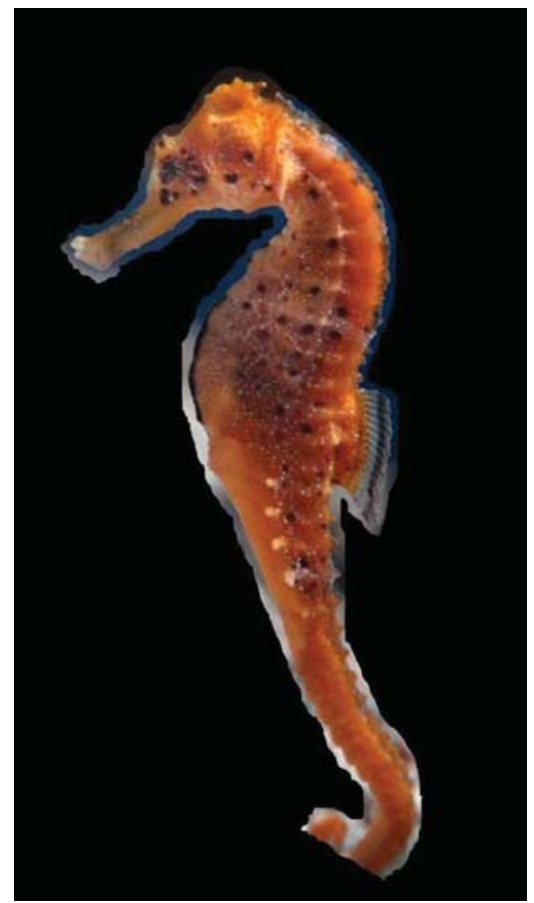

Fig. 2 Caballito de mar. Janeiro, Brazil. Todos los derechos reservados.

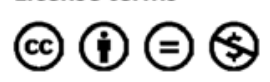

Copyright (c) 2020, Sociedad Argentina de Radiología. Publicado por Thieme Revinter Publicações Ltda., Rio de

\section{License terms}

10.1016/j.rard.2017.05.007

ISSN 1852-9992. 